\title{
Sugarcane inoculated with endophytic diazotrophic bacteria: effects on yield, biological nitrogen fixation and industrial characteristics
}

\author{
JADSON EMANUEL L. ANTUNES ${ }^{1}$, ANA DOLORES S. DE FREITAS ${ }^{2}$, LOUISE M.S. OLIVEIRA ${ }^{3}$, \\ MARIA DO CARMO C.P. DE LYRA ${ }^{4}$, MANOEL A.C. FONSECA ${ }^{5}$, CAROLINA E.R.S. SANTOS ${ }^{2}$, JOSÉ \\ DE PAULA OLIVEIRA ${ }^{6}$, ADEMIR SÉRGIO F. DE ARAÚJO ${ }^{7}$ and MÁRCIA V.B. FIGUEIREDO ${ }^{8}$ \\ ${ }^{1}$ Universidade Federal Rural de Pernambuco, Programa de Pós-Graduação em Ciências do Solo, Departamento \\ de Agronomia, Rua Dom Manoel de Medeiros, s/n, Campus Dois Irmãos, 52171-900 Recife, PE, Brazil \\ ${ }^{2}$ Universidade Federal Rural de Pernambuco, Departamento de Agronomia, Rua Dom \\ Manoel de Medeiros, s/n, Campus Dois Irmãos, 52171-900 Recife, PE, Brazil \\ ${ }^{3}$ Universidade Federal de Pernambuco, Programa de Pós-Graduação em Ciências Biológicas, \\ Av. Prof. Moraes Rego, 1235, Cidade Universitária, 50670-420 Recife, PE, Brazil \\ ${ }^{4}$ Instituto Agronômico de Pernambuco, Laboratório de Genômica, Av. Gal San Martin, 1371, Bongi, 50761-000 Recife, PE, Brazil \\ ${ }^{5}$ Instituto Agronômico de Pernambuco, Estação Experimental de Itapirema, BR 101 Norte, Km 53, 55900-000 Goiana, PE, Brazil \\ ${ }^{6}$ Instituto Agronômico de Pernambuco, Laboratório de Biologia do Solo, Av. \\ Gal. San Martin, 1371, Bongi, 50761-000 Recife, PE, Brazil \\ ${ }^{7}$ Universidade Federal do Piauí, Departamento de Engenharia Agrícola e Solos, Campus \\ Universitário Ministro Petrônio Portella, s/n, Ininga, 64049-550 Teresina, PI, Brazil \\ ${ }^{8}$ Instituto Agronômico de Pernambuco, Laboratório de Biologia do Solo, Av. \\ Gal San Martin, 1371, Bongi, 50761-000 Recife, PE, Brazil
}

Manuscript received on September 20, 2018; accepted for publication on December 11, 2018

\begin{abstract}
How to cite: ANTUNES JEL, FREITAS ADS, OLIVEIRA LMS, LYRA MCCP, FONSECA MAC, SANTOS CERS, OLIVEIRA JP, ARAÚJO ASF AND FIGUEIREDO MVB. 2019. Sugarcane inoculated with endophytic diazotrophic bacteria: effects on yield, biological nitrogen fixation and industrial characteristics. An Acad Bras Cienc 91: e20180990. DOI 10.1590/0001-3765201920180990.
\end{abstract}

\begin{abstract}
The growing need for the use of clean energy has led society to seek alternatives to fossil fuels in order to less pollute the environment. Sugarcane has been known to produce enough biomass and to have associative microorganisms, such as plant growth-promoting bacteria (PGPB), which have the potential to improve the yield of crops. The objective of this study is to evaluate the efficiency and the isotopic dilution of ${ }^{15} \mathrm{~N}$ of microbial inoculants containing endophytic diazotrophic bacteria, individually inoculated and in mixture, on productivity, technological quality and biological nitrogen fixation (BNF) of sugarcane variety RB92579. The experiment was conducted for three consecutive years, comprising different crop cycles, in a completely randomized block design with four replications. The evaluations were at 11 months after planting for plant-cane, and at 12 months after cutting for ratoon cane and second ratoon cane. The contribution of BNF by ${ }^{15} \mathrm{~N}$ natural abundance technique to inoculated treatments ranged from $18 \%$ to $57.31 \%$. This study showed that no strain promoted the improvement on yield and biological nitrogen fixation during the three cycles of sugarcane (plant-cane, ratoon cane and second ratoon cane). However, industrial characteristics of sugar cane can be affectd by PGPB inoculation.
\end{abstract}

Key words: Bacillus megaterium, Herbaspirillum seropecicae, microbial inoculant, natural abundance of ${ }^{15} \mathrm{~N}$, Pseudomonas sp.

Correspondence to: Márcia do Vale Barreto Figueiredo

E-mail: mbarreto@elogica.com.br

ORCID: https://orcid.org/0000-0002-0449-2810 


\section{INTRODUCTION}

The use of nitrogen fertilizers in sugarcane is relatively low in Brazil (40 and $80 \mathrm{~kg} \mathrm{ha}^{-1}$ for plant-cane and second ratoon cane, respectively) when compared with other countries such as India, United States, Colombia and Australia, where the doses used vary between 150 and $200 \mathrm{~kg} \mathrm{ha}^{-1}$ of $\mathrm{N}$ per year. In Brazil, this crop occupies a significant area, and accounts for $35 \%$ of the total nitrogen fertilizer consumed (Baptista et al. 2014). In the world, Brazil is the larger producer of sugarcane being followed by India and China (USDA 2018). However, the national average productivity is relatively low and has remained around $74 \mathrm{t} \mathrm{ha}^{-1}$ in recent years (IBGE 2018). Specifically, the average of productivity found in Northeast was 54 t ha ${ }^{-1}$ being Alagoas and Pernambuco the largest producers (CONAB 2018). The main causes for this low sugarcane productivity are the Brazilian soils with a low fertility and the reduced efficiency of $\mathrm{N}$ use by the crop (Mariano et al. 2017).

On the other hand, the $\mathrm{N}$ use efficiency may be increased by inoculating diazotrophic bacteria, which perform a biological nitrogen fixation process (BNF) in plant tissues (Zhan and Sun 2012) and contribute to the nutrition of the crop. In addition to contributing to nitrogen nutrition, such microorganisms may promote a reduction of pathogen attacks, mitigate the deleterious effects of biotic and abiotic stresses (Lugtenberg and Kamilova 2009), produce growth-promoting substances such as indole-3-acetic acid (Videira et al. 2012), perform solubilization of inorganic phosphate (Shukla et al. 2008), produce siderophores (Beneduzi et al. 2013), among other processes which are beneficial to plants. Such microorganisms are known as plant growth-promoting bacteria (PGPB), and represent an important agricultural and ecological strategy to guarantee economic gains with less damage to the environment (Herrera et al. 2016).
The presence of endophytic diazotrophic microorganisms in sugarcane has been widely studied since the 1950s when the first growthpromoting species were isolated (Döbereiner and Alvahydo 1959). In recent years, studies have confirmed that the interaction between PGPB and sugarcane results in relevant quantities of $\mathrm{N}$ added by BNF (Schultz et al. 2016, Pedula et al. 2016). According to Urquiaga et al. (2012), the contribution of BNF to the nitrogenous nutrition of sugarcane may reach $40 \mathrm{~kg} \mathrm{ha}^{-1}$ of $\mathrm{N}$. Variations in BNF potential may be related to plant genotype and soil, climatic and fertility conditions. However, due to the magnitude of the area planted with sugarcane, the supply of about $30 \%$ of the demand for $\mathrm{N}$ by BNF will certainly bring environmental and economic benefits to this crop (Chaves et al. 2015).

In this context, based on the knowledge that PGPB is a biotechnological tool with a prime importance for the survival and development of cultivated plants, authors raised a hypothesis according to which the inoculation with selected PGPB aims to optimize the growth and the BNF potential of the sugarcane variety RB92579. This hypothesis was tested to investigate the responses of this crop to estimates of the amount of $\mathrm{N}$ fixated and inoculation efficiency in relation to culm yield and technological qualities in plant-cane, ratoon cane and second ratoon cane as a tool for a sustainable crop production. Different PGPB, inoculated isolated and in mixtures, were used to compose microbial inoculants, and various biological parameters were then analyzed.

\section{MATERIALS AND METHODS}

The study was carried out at the Itapirema Experimental Station of the Agronomic Institute of Pernambuco (IPA) in the city of Goiana, state of Pernambuco, Brazil (7³8'33.33" S and $\left.34^{\circ} 56^{\prime} 50.80^{\prime} \mathrm{W}\right)$. The region presents a tropical 
rainy climate (annual average temperature around $28^{\circ} \mathrm{C}$, with a dry summer) according to the Köppen classification (Am). The soil of the experimental area is a Carbic Spodosol according to USDA (1999) and Embrapa (2013), with a sandy texture, featuring, in the $0-20 \mathrm{~cm}$ layer, the following attributes, according to the methodology recommended by Embrapa (2017): $890 \mathrm{~g} \mathrm{~kg}^{-1}$ of sand, $10 \mathrm{~g} \mathrm{~kg}^{-1}$ of silt and $100 \mathrm{~g} \mathrm{~kg}^{-1}$ of clay; density $=1.49 \mathrm{~g} \mathrm{~cm}^{-3} ; 0.06 \mathrm{dag} \mathrm{kg}^{-1}$ of organic matter; $\mathrm{pH}$ $\left(\right.$ water 1:2.5) $=5.7 ; \mathrm{P}($ Mehlich $\mathrm{I})=43 \mathrm{mg} \mathrm{dm}^{-3}$; and $1.10,1.65,0.02,0.03,0.05$ and $2.01 \mathrm{cmolc} \mathrm{dm}^{-3}$ of $\mathrm{Ca}^{2+}, \mathrm{Mg}^{2+}, \mathrm{Na}^{+}, \mathrm{K}^{+}, \mathrm{Al}^{3+}$ and $\mathrm{H}^{+}$, respectively.

The experiment was conducted using a completely randomized blocks design with 10 treatments: eight treatments with different inoculations of diazotrophic bacteria and two control treatments without the inoculation (one with nitrogen fertilization and the other without nitrogen fertilization), and four replications. The treatment with nitrogen fertilization consisted of 20 $\mathrm{kg} \mathrm{ha}^{-1}$ of $\mathrm{N}$ as base fertilization conducted at the time of planting, and $40 \mathrm{~kg} \mathrm{ha}^{-1} \mathrm{~N}$ along the side of the planting line 90 days after the first application (Cavalcanti et al. 2008). Each plot was composed of five lines of $8.0 \mathrm{~m}$ in length, with a spacing of $1.3 \mathrm{~m}$ between rows, totaling $52 \mathrm{~m}^{2}$, considering as useful area the three central lines, excluding 1.0 $\mathrm{m}$ from each side, totaling a useful area of $23.4 \mathrm{~m}^{2}$ for each plot. The total area of the experiment was $3,312 \mathrm{~m}^{2}$. At 8 months after sugarcane planting, extra plots were installed at the ends of each block, in which sunflower (Helianthus annuus L.) seeds were sown with the objective of estimating the $\delta^{15} \mathrm{~N}$ of the soil $\mathrm{N}$ available for sugarcane.

The experiment was conducted during three consecutive years, in which the accumulated precipitation was $1,418 \mathrm{~mm}, 1,950 \mathrm{~mm}$ and 1,643 $\mathrm{mm}$. The evaluations of plant-cane were carried out 11 months after planting, 12 months after the first cut for ratoon cane, and 12 months after the second cut for the second ratoon cane. In plant-cane and ratoon cane cycles, soil moisture was kept close to $80 \%$ of field capacity by the application of a water blade according to the needs of the crop. During the second ratoon cane cycle, the plants were not irrigated because of the soil temperature was lower and maintained the soil moisture suitable for cane development.

The inoculants were prepared with the strains IPA-CC9 (Herbaspirillum seropedicae), IPA-CC33 (Pseudomonas sp.) and IPA-CF65 (Bacillus megaterium), applied isolated and in various mixtures, and with strains composing the inoculant as recommended by the Brazilian Agricultural Research Corporation (Embrapa) for sugarcane. The strains IPA-CC9, IPA-CC33 and IPA-CF65 are plant growth-promoting bacteria (PGPB) isolated from local sugarcane tissues (Antunes et al. 2017). The following mixtures of strains were used: IPA-CC9+IPA-CC33, IPACC9+IPA-CF65, IPA-CC33+IPA-CF65, IPACC9+IPA-CC33+IPA-CF65IPA-CC9+IPA-CC33, IPA-CC9+IPA-CF65, IPA-CC33+IPA-CF65, IPACC9+IPA-CC33+IPA-CF65. The mixed inoculant recommended by Embrapa was prepared using the strains BR1140 (Azospirillum amazonense), BR11175 (Herbaspirillum seropedicae), BR11192 (Herbaspirillum rubrisubalbicans), BR11284 (Gluconacetobacter diazotrophicus) and BR11364 (Burkholderia tropica) (Oliveira et al. 2006).

All strains were grown in monoxenic conditions in Erlenmeyer flasks containing DYGS liquid medium (Baldani et al. 2014), with a specific $\mathrm{pH}$ for each genus of bacteria, in a rotating shaker (200 rpm), for 48 hours at $31^{\circ} \mathrm{C}$. After growth, bacteria were individually inoculated under aseptic conditions in sterile peat (Figueiredo et al. 2013) and distributed in medium density polyethylene bags $(0.04-0.09 \mathrm{~mm})$. The final composition of each dose of inoculant was $50 \mathrm{~mL}$ of bacterial growth mixed with $150 \mathrm{~g}$ of peat medium, totaling a final product with $200 \mathrm{~g}$ and $10^{9}$ cells per gram of peat. After preparation, the inoculants were stored 
for maturation at room temperature $\left(28-30^{\circ} \mathrm{C}\right)$ for seven days.

One month before planting, the soil acidity was corrected by applying $800 \mathrm{~kg} \mathrm{ha}^{-1}$ of dolomitic limestone. The area was prepared with plowing and harrowing, followed by opening of grooves $30 \mathrm{~cm}$ deep. For planting, we used segments of culms with 3 buds cut from 10-month-old sugarcane plants of the variety RB92579, which is one of the most used varieties in the northeast region of Brazil. All treatments received fertilization according to the recommendations for the crop (Cavalcanti et al. 2008): $120 \mathrm{~kg} \mathrm{ha}^{-1}$ of $\mathrm{P}_{2} \mathrm{O}_{5}$ as single superphosphate, $40 \mathrm{~kg} \mathrm{ha}^{-1}$ of $\mathrm{K}_{2} \mathrm{O}$ as $\mathrm{KCl}$ at the bottom of the groove at the time of planting, and $40 \mathrm{~kg} \mathrm{ha}^{-1}$ of $\mathrm{K}_{2} \mathrm{O}$ as $\mathrm{KCl}$ next to the planting line 90 days after planting.

The inoculation was performed prior to planting following the methodology described by Oliveira et al. (2002). Then, the culm segments were placed in raffia bags and immersed for 60 minutes in reservoirs containing the turfous inoculant diluted at a ratio of $200 \mathrm{~g}$ of inoculant for $30 \mathrm{~L}$ of water. The culms were planted immediately after inoculation, leaving between 14 and 20 buds per linear meter of furrow (300 culms per treatment).

In order to determine the contribution of BNF for sugarcane nutrition, samples of 10 index leaves $(+3)$, which indicate nutritional status and represent the average enrichment value of ${ }^{15} \mathrm{~N}$ for the whole plant (Boddey et al. 2001), were collected in the central rows of the experimental units at 11 months of plant-cane cultivation. At the same time, we also collected samples composed of green and healthy leaves of five sunflower plants, randomly selected within each extra plot of each block. Leaves of different individuals of two species of spontaneous plants, which appeared between the rows of sugarcane, were collected and identified at a species level. All vegetable samples were oven-dried at $65^{\circ} \mathrm{C}$ for 72 hours and then ground. For analysis, sub-samples were reduced to a fine powder using a roller mill. Aliquots were placed in a capsule and loaded into a Thermo Quest-Finnigan Delta Plus isotope ratio mass spectrometer (FinniganMAT; CA, USA) interfaced with an Elemental Analyzer (Carlo Erba model 1110; Milan, Italy) at the Laboratory of Isotope Ecology (CENAUSP, Brazil) to obtain the nitrogen and carbon isotope ratio and the total nitrogen content. Natural abundances of ${ }^{15} \mathrm{~N}$ and ${ }^{13} \mathrm{C}$ were expressed using 'delta' notation (\%):

$$
\begin{aligned}
& \delta=\left(\mathrm{R}_{\text {sample }} / \mathrm{R}_{\text {standard }}-1\right) \times 1000 \\
& \text { where: } \mathrm{R}_{\text {sample }} \text { and } \mathrm{R}_{\text {standard }} \text { are }{ }^{15} \mathrm{~N}:{ }^{14} \mathrm{~N} \text { and }
\end{aligned}
$$
${ }^{13} \mathrm{C}:{ }^{12} \mathrm{C}$ ratios of samples and of standards, which are atmospheric $\mathrm{N}_{2}$ for $\mathrm{N}$, and Pee Dee Belemnite for $\mathrm{C}$.

Atmospheric nitrogen fixation by sugarcane was assumed to have occurred when the $\delta^{15} \mathrm{~N}$ difference between the average value of the reference plant and the sugarcane leaf value was $>2 \%$ (Freitas et al. 2015, Dos Santos et al. 2017). Estimates of the proportion of plant nitrogen derived from the atmosphere $(\% \mathrm{Ndfa})$ were made using the ${ }^{15} \mathrm{~N}$ natural abundance technique and the formula recommended by Shearer and Kohl (1986):

$$
\% \mathrm{Ndda}=\left[\left(\delta^{15} \mathrm{~N}_{\text {(reference) }}-\delta^{15} \mathrm{~N}_{\text {(fixing) }}\right) / \delta^{15} \mathrm{~N}_{\text {(reference) }}\right.
$$
-B] x 100

where: $\delta^{15} \mathrm{~N}_{\text {(reference) }}$ is the average value of $\delta^{15} \mathrm{~N}$ signals of reference plants, $\delta^{15} \mathrm{~N}_{\text {(fixing) }}$ is the average value of $\delta^{15} \mathrm{~N}$ signals of sugarcane and $\mathrm{B}$ is the $\delta^{15} \mathrm{~N}$ value for fixing sugarcane plants grown in the absence of $\mathrm{N}$. As the growth relying entirely on BNF from grass species have not yet been achieved, the value was assumed to be zero (the same abundance of ${ }^{15} \mathrm{~N}$ as the air), as described by Urquiaga et al. (2012).

We performed four different $\% \mathrm{Ndda}$ estimates using the $\delta^{15} \mathrm{~N}$ values of different reference plants (spontaneous species and sunflowers) to estimate the $\delta^{15} \mathrm{~N}$ of the $\mathrm{N}$ available in the soil for sugarcane: two using the spontaneous plants collected, one using the sunflower and one using the average of the three species. 
After the two cuts of sugarcane, rootstock fertilization was carried out with $40 \mathrm{~kg} \mathrm{ha}^{-1}$ of $\mathrm{P}_{2} \mathrm{O}_{5}$ as single superphosphate, and $100 \mathrm{~kg} \mathrm{ha}^{-1}$ of $\mathrm{K}_{2} \mathrm{O}$ as $\mathrm{KCl}$ for all treatments. The nitrogen control treatment received $80 \mathrm{~kg} \mathrm{ha}^{-1}$ of $\mathrm{N}$ as urea. In the ratoon cane cycle, no re-inoculation was performed. The re-inoculation of the second rootstock was performed with a manual spray after the cut, with a jet directed to the surface of the cut in the respective treatments. We used $750 \mathrm{ml}$ of each inoculant, prepared in the same manner as described above, diluted at 1:5 and containing a final concentration of approximately $10^{7}$ cells $\mathrm{mL}^{-1}$.

At the end of each sugarcane crop cycle, all plants in the useful area were harvested by hand, and the leaves and stems of all plants were weighed separately. Leaf sub-samples were collected for determination of moisture content and dry weight estimation. The amount of nitrogen accumulated in leaves was calculated by multiplying the total nitrogen by the respective leaf biomass. Fixed $\mathrm{N}$ was calculated by multiplying $\% \mathrm{Ndda}$ by the total $\mathrm{N}$ accumulated by the plant. Sub-samples composed of ten culms, harvested at random in the useful area of each plot, were used to determine the industrial/technological parameters (ton of pol in the sugarcane juice per hectare (TPH), total soluble solids ( ${ }^{\circ}$ Brix) and percentage of fibers.

Data normality was tested using the ShapiroWilk test (W) and, because this condition was met in all cases, an analysis of variance was performed with the application of the F test. All means were compared by Duncan test $(\mathrm{P}<0.05)$ using the SAS software version 8.02 (SAS Institute 2001), considering a randomized block experiment with a factorial design (the 3 evaluation cycles). The average $\delta^{15} \mathrm{~N}$ value of sugarcane was compared with the average values of sunflower using the $T$ test at $\mathrm{p}=0.05$.

\section{RESULTS AND DISCUSSION}

The yield of culms did not differ between plantcane and ratoon cane, but was severely decreased in the second ratoon cane cycle (Table I). In no cycle did productivity respond to nitrogen fertilization or inoculation with the strains or mixtures of strains. The $\mathrm{N}$ concentrations in leaves did not vary with the treatments, while varied between cycles. Thus, the amount of $\mathrm{N}$ accumulated in leaves was higher in the first sugarcane cycle than in subsequent cycles (Table I), while that the inoculations or the nitrogen fertilization exerted no effects on this parameter.

At eleven months after planting, there was no difference between the $\delta^{15} \mathrm{~N}$ values of inoculated plants and neither of these plants in relation to noninoculated plants, whether they received nitrogen fertilizer or not (Table II).

Sugarcane always presented $\delta^{15} \mathrm{~N}$ values lower than reference plants, although the values were relatively close to those found for Tumera ulmifolia. Using this species as a reference, it is only possible to detect BNF in plants inoculated with the mixtures IPA-CC33+IPA-CF65 and IPACC9+IPA-CC33+IPA-CF65 and in non-inoculated plants. Using Solanum paniculatum, sunflower or the average of the three species as references, it is possible to estimate atmospheric $\mathrm{N}$ contributions to sugarcane nutrition both inoculated and not inoculated, and even to plants that received nitrogen fertilization. This result indicates that suitable plant species are yet a limiting factor for natural ${ }^{15} \mathrm{~N}$ abundance calculation. Indeed, according to the different ways of calculating, the contributions may vary between 18 and 57\% (Table I). Considering only the calculations of $\% \mathrm{Ndda}$ using the means of all reference plants (Table II), the $\mathrm{N}$ amounts fixed in leaves did not present differences between the different inoculation treatments or nitrogen fertilization treatments, varying between 12 and $27 \mathrm{~kg} \mathrm{ha}^{-1}$. 
TABLE I

Productivity of fresh culms $\left(\mathrm{Mg} \mathrm{ha}^{-1}\right)$ and Nitrogen accumulated in leaves $\left(\mathrm{kg} \mathrm{ha}^{-1}\right)$ of sugarcane, cultivar RB92579, not inoculated or inoculated with endophytic diazotrophic bacteria, in three consecutive years of cultivation in the municipality of Goiana, PE, Brazil.

\begin{tabular}{|c|c|c|c|}
\hline Treatment & Plant-Cane & First-Ratoon & Second-Ratoon \\
\hline & \multicolumn{3}{|c|}{ Fresh culms $\left(\mathrm{Mg} \mathrm{ha}^{-1}\right)$} \\
\hline IPA-CC9 & $74.75 \pm 8.87 \mathrm{aA}$ & $86.75 \pm 2.84 \mathrm{aA}$ & $37.50 \pm 1.84 \mathrm{aB}$ \\
\hline IPA-CC33 & $71.25 \pm 9.44 \mathrm{aA}$ & $76.50 \pm 4.64 \mathrm{aA}$ & $38.50 \pm 1.50 \mathrm{aB}$ \\
\hline IPA-CF65 & $83.75 \pm 9.80 \mathrm{aA}$ & $86.75 \pm 4.64 \mathrm{aA}$ & $44.75 \pm 2.95 \mathrm{aB}$ \\
\hline IPA-CC9 + IPA-CC33 & $77.75 \pm 7.27 \mathrm{aA}$ & $80.50 \pm 4.50 \mathrm{aA}$ & $41.25 \pm 2.66 \mathrm{aB}$ \\
\hline IPA-CC9+IPA-CF65 & $67.25 \pm 4.73 \mathrm{aA}$ & $83.75 \pm 3.61 \mathrm{aA}$ & $37.75 \pm 3.72 \mathrm{aB}$ \\
\hline IPA-CC33+IPA-CF65 & $79.56 \pm 11.81 \mathrm{aA}$ & $82.75 \pm 9.88 \mathrm{aA}$ & $38.75 \pm 2.86 \mathrm{aB}$ \\
\hline IPA-CC9+IPA-CC33+IPA-CF65 & $63.02 \pm 8.44 \mathrm{aA}$ & $77.75 \pm 3.32 \mathrm{aA}$ & $37.50 \pm 3.09 \mathrm{aB}$ \\
\hline EMBRAPA & $77.50 \pm 7.41 \mathrm{aA}$ & $80.00 \pm 7.92 \mathrm{aA}$ & $37.50 \pm 2.32 \mathrm{aB}$ \\
\hline Not inoculated + nitrogen fertilizer & $72.75 \pm 1.03 \mathrm{aA}$ & $72.25 \pm 5.93 \mathrm{aA}$ & $39.00 \pm 4.35 \mathrm{aB}$ \\
\hline Not inoculated & $78.75 \pm 8.05 \mathrm{aA}$ & $84.25 \pm 6.02 \mathrm{aA}$ & $36.00 \pm 3.32 \mathrm{aB}$ \\
\hline \multicolumn{4}{|l|}{$\mathrm{CV}=23,02 \%$} \\
\hline & \multicolumn{3}{|c|}{ Nitrogen accumulated in leaves $\left(\mathrm{kg} \mathrm{ha}^{-1}\right)$} \\
\hline IPA-CC9 & $55.62 \pm 7.45 \mathrm{aA}$ & $27.26 \pm 1.69 \mathrm{aB}$ & $23.55 \pm 2.59 \mathrm{aB}$ \\
\hline IPA-CC33 & $51.70 \pm 3.92 \mathrm{aA}$ & $29.68 \pm 1.02 \mathrm{aB}$ & $29.29 \pm 1.21 \mathrm{aB}$ \\
\hline IPA-CF65 & $56.67 \pm 6.89 \mathrm{aA}$ & $38.25 \pm 8.63 \mathrm{aAB}$ & $27.20 \pm 3.45 \mathrm{aB}$ \\
\hline IPA-CC9+IPA-CC33 & $61.80 \pm 4.19 \mathrm{aA}$ & $29.41 \pm 3.04 \mathrm{aB}$ & $26.00 \pm 2.85 \mathrm{aB}$ \\
\hline IPA-CC9+IPA-CF65 & $55.61 \pm 4.28 \mathrm{aA}$ & $29.14 \pm 3.06 \mathrm{aB}$ & $23.90 \pm 3.31 \mathrm{aB}$ \\
\hline IPA-CC33+IPA-CF65 & $67.32 \pm 3.11 \mathrm{aA}$ & $30.06 \pm 4.88 \mathrm{aB}$ & $22.36 \pm 1.30 \mathrm{aB}$ \\
\hline IPA-CC9+IPA-CC33+IPA-CF65 & $53.39 \pm 3.66 \mathrm{aA}$ & $24.58 \pm 1.64 \mathrm{aB}$ & $24.56 \pm 4.70 \mathrm{aB}$ \\
\hline EMBRAPA & $50.51 \pm 4.65 \mathrm{aA}$ & $33.85 \pm 5.10 \mathrm{aB}$ & $26.04 \pm 2.02 \mathrm{aB}$ \\
\hline Not inoculated + nitrogen fertilizer & $58.47 \pm 5.49 \mathrm{aA}$ & $33.74 \pm 3.74 \mathrm{aB}$ & $20.78 \pm 2.71 \mathrm{aB}$ \\
\hline Not inoculated & $62.44 \pm 10.31 \mathrm{aA}$ & $32.71 \pm 2.70 \mathrm{aB}$ & $23.03 \pm 3.44 \mathrm{aB}$ \\
\hline $\mathrm{CV}=16.57 \%$ & & & \\
\hline
\end{tabular}

Means followed by the same letters, lowercase in rows and uppercase in lines, for each parameter, do not differ by Duncan's test $(\mathrm{p}<0.05)$. Inoculants: IPA-CC9 = Herbaspirillum seropedicae, IPA-CC33 = Pseudomonas sp., IPA-CF65 = Bacillus megaterium, EMBRAPA = mixture of the strains BR1140 (Azospirillum amazonense), BR11175 (H. seropedicae), BR11192 (H. rubrisubalbicans), BR11284 (Gluconacetobacter diazotrophicus) and BR11364 (Burkholderia tropica).

The decrease in culm yield in the third cycle (Table I) was not accompanied by the decrease in ${ }^{\circ}$ Brix, but affected the sugar production per hectare, which decreased by $50 \%$ (Table III). In some treatments, the industrial quality of the second ratoon cane decreased, and there was an increase in fiber content. In the three crop cycles, there was difference between the mixture of strains IPA-CC9 + IPA-CC 33 and the strain EMBRAPA for TPH parameter (Table III). In the first cycle, the inoculation with the strain IPA-CC33 decreased the sugarcane ${ }^{\circ}$ Brix in relation to the absolute control, but this effect was not observed in subsequent cycles. In the second cycle, the mixture of strains IPA-CC9+IPA-CF65 increased the sugarcane ${ }^{\circ}$ Brix in relation to $\mathrm{TN}$, and again this effect was not observed in the other cycles. In second ratoon cane, plants inoculated with the mixture IPA-CC9+IPACC33 produced more sugar per hectare than plants inoculated with the EMBRAPA mixture or plants that did not receive inoculation or chemical fertilization. In ratoon cane, the plants inoculated 
TABLE II

Values of $\delta^{15} \mathrm{~N}(\%)$ of + 3 leaves of sugarcane, cultivar RB92579, and of non-N-fixing plants, and estimates of proportion of $\mathbf{N}$ derived from the atmosphere (\%Ndda) in sugarcane, cultivar RB92579, not inoculated or inoculated with endophytic diazotrophic bacteria, at 11 months after planting during the plant-cane cycle, in the city of Goiana, PE, Brazil.

\begin{tabular}{|c|c|c|c|c|c|}
\hline Inoculation & $\delta^{15} \mathrm{~N}(\%)^{*}$ & $\% \mathrm{Ndda}^{1}$ & $\% \mathrm{Ndda}^{2}$ & $\% \mathrm{Ndda}^{3}$ & $\% \mathrm{Ndda}^{4}$ \\
\hline References & 4.77 & & & & \\
\hline Solanum paniculatum (Solanaceae) & 4.90 & - & - & - & - \\
\hline Tumera ulmifolia (Tumeraceae) & 3.58 & - & - & - & - \\
\hline Sun flower (Asteraceae) & $5.81 \pm 0.94$ & - & - & - & - \\
\hline \multicolumn{6}{|l|}{ Sugarcane } \\
\hline IPA-CC9 & $2.64 \mathrm{a}^{*}$ & 46.08 & 0 & 54.56 & 42.26 \\
\hline IPA-CC33 & $2.76 \mathrm{a}^{*}$ & 43.63 & 0 & 52.50 & 39.64 \\
\hline IPA-CF65 & $2.96 \mathrm{a}^{*}$ & 39.54 & 0 & 49.09 & 35.27 \\
\hline IPA-CC9+IPA-CC33 & $3.17 \mathrm{a}^{*}$ & 35.25 & 0 & 45.44 & 30.67 \\
\hline IPA-CC9+IPA-CF65 & $2.78 a^{*}$ & 43.22 & 0 & 52.15 & 39.20 \\
\hline IPA-CC33+IPA-CF65 & $2.93 \mathrm{a}^{*}$ & 40.16 & 18.04 & 49.57 & 35.92 \\
\hline IPA-CC9+IPA-CC33+IPA-CF65 & $2.48 \mathrm{a}^{*}$ & 49.35 & 30.63 & 57.31 & 45.76 \\
\hline EMBRAPA & $3.41 \mathrm{a}^{*}$ & 30.35 & 0 & 41.31 & 25.42 \\
\hline Not inoculated + nitrogen fertilizer & $2.58 \mathrm{a}^{*}$ & 47.30 & 27.83 & 55.59 & 43.58 \\
\hline Not inoculated & $2.49 \mathrm{a}^{*}$ & 49.14 & 30.35 & 57.14 & 45.54 \\
\hline $\mathrm{CV}=27.12 \%$ & & & & & \\
\hline
\end{tabular}

* Averages significantly different from sunflower averages at a 0.01 probability level (T test). Means followed by the same letters do not differ by Duncan test $(\mathrm{p} \leq 0.05) .{ }^{1}$ Calculated using S. paniculatum as a reference plant; ${ }^{2}$ Calculated using T. ulmifolia as a reference plant; ${ }^{3}$ Calculated using $H$. annuus as a reference plant; ${ }^{4}$ Calculated using the mean of all reference species (S. paniculatum, T. ulmifolia and H. Annuus).

with the mixture IPA-CC9+IPA-CC33+IPACF65 showed higher amount of fiber than plants inoculated with the inoculant from EMBRAPA, similar to control without inoculation. In the third cycle, the content of fiber was lower in plants inoculated with the strain IPA-CC9.

As expected, the productivity and the amount of $\mathrm{N}$ accumulated in sugarcane leaves decreased over time (Table I). The sudden decrease observed in second ratoon cane is a result of the low availability of water (the cultivation was made in a dry condition). Despite a low natural fertility (890 $\mathrm{g} \mathrm{kg}^{-1}$ of sand, $\mathrm{P}=43 \mathrm{mg} \mathrm{dm}^{-3}$ ) and a low organic matter content $\left(0.06 \mathrm{dag} \mathrm{kg}^{-1}\right)$ of the soil in the experimental area, the inoculation of sugarcane with diazotrophic bacteria or the application of nitrogen fertilizer exerted no effects on culm yield in any of the three crop cycles.

In general, low plant-cane responses to nitrogen fertilization are observed in Brazil, especially in soils with a high natural fertility. This is possibly due to the presence of organic matter in the soil, which supplies a good part of the plant's needs, and by BNF (Rossetto et al. 2010; Urquiaga et al. 2012). Thus, better responses to the use of diazotrophic bacteria are expected in soils with a medium to low natural fertility (Oliveira et al. 2006). However, our results evidence that, even when cultivated on a low fertility soil, the variety RB92579 did not require nitrogen fertilization nor inoculation with bacteria capable of performing BNF in vitro. This may be explained by the existence of native 
TABLE III

Total soluble solids $\left({ }^{\circ} \mathrm{Brix}\right)$, ton of pol per hectare/sugar yield (TPH) and average fiber contents (Fiber) of sugarcane, cultivar RB92579, not inoculated or inoculated with endophytic diazotrophic bacteria, in three consecutive years of cultivations, in the municipality of Goiana, PE, Brazil.

\begin{tabular}{|c|c|c|c|}
\hline \multirow{2}{*}{ Treatment } & Plant-Cane & First-Ratoon & Second-Ratoon \\
\hline & \multicolumn{3}{|c|}{${ }^{\circ}$ Brix (\%) } \\
\hline IPA-CC9 & $21.05 \pm 0.32 \mathrm{abA}$ & $21.20 \pm 0.57 \mathrm{bA}$ & $20.78 \pm 0.27 \mathrm{aA}$ \\
\hline IPA-CC33 & $20.16 \pm 0.46 \mathrm{bB}$ & $21.83 \pm 0.48 \mathrm{abA}$ & $21.04 \pm 0.14 \mathrm{aAb}$ \\
\hline IPA-CF65 & $20.87 \pm 0.30 \mathrm{abA}$ & $21.15 \pm 0.21 \mathrm{bA}$ & $21.59 \pm 0.22 \mathrm{aA}$ \\
\hline IPA-CC9 + IPA-CC33 & $21.85 \pm 0.20 \mathrm{aA}$ & $21.15 \pm 0.27 \mathrm{bB}$ & $21.47 \pm 0.11 \mathrm{aAB}$ \\
\hline IPA-CC9+IPA-CF65 & $21.59 \pm 0.12 \mathrm{aAB}$ & $22.46 \pm 0.09 \mathrm{aA}$ & $20.94 \pm 0.76 \mathrm{aB}$ \\
\hline IPA-CC33+IPA-CF65 & $20.99 \pm 0.59 \mathrm{abA}$ & $21.60 \pm 0.20 \mathrm{abA}$ & $21.94 \pm 0.21 \mathrm{aA}$ \\
\hline IPA-CC9+IPA-CC33+IPA-CF65 & $21.73 \pm 0.60 \mathrm{aA}$ & $21.38 \pm 0.27 \mathrm{bA}$ & $21.54 \pm 0.44 \mathrm{aA}$ \\
\hline EMBRAPA & $21.05 \pm 0.30 \mathrm{abA}$ & $21.30 \pm 0.17 \mathrm{bA}$ & $20.96 \pm 0.40 \mathrm{aA}$ \\
\hline Not inoculated + nitrogen fertilizer & $20.72 \pm 0.37 \mathrm{abA}$ & $21.42 \pm 0.38 \mathrm{bA}$ & $21.07 \pm 0.25 \mathrm{aA}$ \\
\hline Not inoculated & $21.55 \pm 0.16 \mathrm{aA}$ & $22.17 \pm 0.22 \mathrm{abA}$ & $20.76 \pm 0.29 \mathrm{aB}$ \\
\hline \multicolumn{4}{|l|}{$\mathrm{CV}=3.24 \%$} \\
\hline & \multicolumn{3}{|c|}{ TPH (Mg. pol. ha' $\left.{ }^{-1}\right)$} \\
\hline IPA-CC9 & $11.51 \pm 1.30 \mathrm{aA}$ & $13.75 \pm 0.31 \mathrm{aA}$ & $6.87 \pm 0.45 \mathrm{abB}$ \\
\hline IPA-CC33 & $10.69 \pm 1.51 \mathrm{aA}$ & $12.71 \pm 1.04 \mathrm{aA}$ & $6.72 \pm 0.28 \mathrm{abB}$ \\
\hline IPA-CF65 & $13.11 \pm 1.44 \mathrm{aA}$ & $13.85 \pm 0.71 \mathrm{aA}$ & $8.14 \pm 0.61 \mathrm{abB}$ \\
\hline IPA-CC9 + IPA-CC33 & $12.96 \pm 1.32 \mathrm{aA}$ & $12.97 \pm 0.84 \mathrm{aA}$ & $8.60 \pm 0.79 \mathrm{aB}$ \\
\hline IPA-CC9+IPA-CF65 & $10.90 \pm 1.25 \mathrm{aB}$ & $14.23 \pm 0.59 \mathrm{aA}$ & $6.69 \pm 0.59 \mathrm{abC}$ \\
\hline IPA-CC33+IPA-CF65 & $12.50 \pm 1.91 \mathrm{aA}$ & $13.66 \pm 1.54 \mathrm{aA}$ & $7.21 \pm 0.42 \mathrm{abB}$ \\
\hline IPA-CC9+IPA-CC33+IPA-CF65 & $10.32 \pm 1.74 \mathrm{aA}$ & $12.61 \pm 0.49 \mathrm{aA}$ & $6.65 \pm 0.62 \mathrm{abB}$ \\
\hline EMBRAPA & $12.34 \pm 1.27 \mathrm{aA}$ & $12.97 \pm 1.30 \mathrm{aA}$ & $6.40 \pm 0.35 \mathrm{bB}$ \\
\hline Not inoculated + nitrogen fertilizer & $10.90 \pm 0.30 \mathrm{aA}$ & $11.85 \pm 1.06 \mathrm{aA}$ & $6.91 \pm 0.78 \mathrm{abB}$ \\
\hline Not inoculated & $12.55 \pm 1.24 \mathrm{aA}$ & $14.06 \pm 0.99 \mathrm{aA}$ & $6.33 \pm 0.73 \mathrm{bB}$ \\
\hline \multicolumn{4}{|l|}{$\mathrm{CV}=19.17 \%(\%)$} \\
\hline & \multicolumn{3}{|c|}{ Fiber $(\%)$} \\
\hline IPA-CC9 & $13.57 \pm 0.32 \mathrm{aA}$ & $13.91 \pm 0.16 \mathrm{abA}$ & $14.03 \pm 0.80 \mathrm{bA}$ \\
\hline IPA-CC33 & $13.34 \pm 0.29 \mathrm{aB}$ & $13.99 \pm 0.29 \mathrm{abAB}$ & $15.02 \pm 0.38 \mathrm{aA}$ \\
\hline IPA-CF65 & $13.17 \pm 0.35 \mathrm{aB}$ & $14.38 \pm 0.38 \mathrm{abAB}$ & $15.04 \pm 0.80 \mathrm{aA}$ \\
\hline IPA-CC9 + IPA-CC33 & $13.21 \pm 0.21 \mathrm{aB}$ & $13.94 \pm 0.33 \mathrm{abB}$ & $15.28 \pm 0.32 \mathrm{aA}$ \\
\hline IPA-CC9+IPA-CF65 & $13.36 \pm 0.22 \mathrm{aA}$ & $14.08 \pm 0.29 \mathrm{abA}$ & $13.63 \pm 0.22 \mathrm{aA}$ \\
\hline IPA-CC33+IPA-CF65 & $13.24 \pm 0.22 \mathrm{aA}$ & $14.22 \pm 0.12 \mathrm{abA}$ & $14.32 \pm 0.73 \mathrm{aA}$ \\
\hline IPA-CC9+IPA-CC33+IPA-CF65 & $13.62 \pm 0.27 \mathrm{aB}$ & $14.67 \pm 0.34 \mathrm{aAB}$ & $15.64 \pm 0.76 \mathrm{aA}$ \\
\hline EMBRAPA & $12.80 \pm 0.18 \mathrm{aB}$ & $13.58 \pm 0.24 \mathrm{bB}$ & $15.11 \pm 0.86 \mathrm{aA}$ \\
\hline Not inoculated + nitrogen fertilizer & $13.18 \pm 0.45 \mathrm{aA}$ & $14.00 \pm 0.15 \mathrm{abA}$ & $14.37 \pm 0.75 \mathrm{aA}$ \\
\hline Not inoculated & $13.08 \pm 0.30 \mathrm{aB}$ & $14.01 \pm 0.32 \mathrm{abAB}$ & $14.59 \pm 0.55 \mathrm{aA}$ \\
\hline
\end{tabular}

Means followed by the same letters, lowercase in rows and uppercase in lines, for each parameter, do not differ by Duncan's test $(\mathrm{p}<0.05)$. Inoculants: IPA-CC9 = Herbaspirillum seropedicae, IPA-CC33 = Pseudomonas $\mathrm{sp}$., IPA-CF65 = Bacillus megaterium, EMBRAPA = mixture of the strains BR1140 (Azospirillum amazonense), BR11175 (H. seropedicae), BR11192 (H. rubrisubalbicans), BR11284 (Gluconacetobacter diazotrophicus) and BR11364 (Burkholderia tropica). 
endophytic and/or epiphytic diazotrophic bacteria native to sugarcane-seeds and to the soil, which contributes to the low plant-cane response to the nitrogen applied.

Although in this study the results have not shown effect of inoculation on sugarcane, some studies have been demonstrating that inoculation with diazotrophic bacteria may increase the production of sugarcane biomass (Chaves et al. 2015, Dos Santos et al. 2017), although the observed increases in yield may be related to different effects of growth promotion of the root system of the crop (Videira et al. 2012). However, the lack of response to inoculation is also frequently reported for different varieties and soil-climatic conditions (Lima et al. 2011, Schultz et al. 2014, 2016). Even when using recommended bacterial mixtures (Gluconacetobacter diazotrophicus, Herbaspirillum seropedicae, Herbaspirillum rubrisubalbicans, Azospirillum amazonense and Burkholderia tropica) for the inoculation of sugarcane, increases in biomass production and accumulation of $\mathrm{N}$ may not be significant (Silva et al. 2009). On the hand, the results confirm the lack of response to $\mathrm{N}$ fertilizer by sugarcane and, on the other hand, highlight the need to search and evaluate new and efficient bacterial strains for different soil and environmental conditions found in Northeast.

For planting, segments of culms with 3 buds cut from sugarcane plants cultivated in field were used. It is likely that the population of naturally occurring diazotrophic bacteria in culms (Antunes et al. 2017) was efficient to meet the needs for $\mathrm{N}$ of plants through BNF. The $\mathrm{N}$ signal of the soil available for plants, estimated by the isotopic enrichment of three species of reference plants (two spontaneous species and a sunflower), was higher than that of sugarcane regardless of whether nitrogen fertilizer or inoculation was used (Table II). When compared to sunflower, sugarcane always presented a statistically different impoverishment of over $2 \%$, which has been considered a reliable situation for BNF estimation by the natural abundance method (Freitas et al. 2010).

The use of the natural ${ }^{15} \mathrm{~N}$ abundance methodology for estimating BNF in sugarcane still has limitations, such as a difficulty in finding an appropriate reference plant to estimate the isotopic $\mathrm{N}$ signal of the soil available for plants. Thus, it is important to select a control plant that uses a good soil volume and absorbs nutrients in a time pattern similar to that of the target plant (fixing species), that is, it is important that the control and the target plant present a similar phenology and similar growth habits (Freitas et al. 2010). This condition is rarely met in studies on sugarcane. For this reason, several calculation simulations of $\% \mathrm{Ndda}$, and also the mean of $\delta^{15} \mathrm{~N}$ of all references, have been made using each reference species separately (Table II). A similar procedure has been adopted in other experiments to estimate BNF in sugarcane (Boddey et al. 2003).

According to the different ways of calculating the contribution of atmospheric $\mathrm{N}$ to the accumulation of $\mathrm{N}$ in sugarcane (Table II), BNF estimates ranged from 0 (for some inoculation treatments, when using Tumera ulmifolia as a reference plant) to $57 \%$ (in the absolute control using the triple mixture of native isolates and sunflower as a reference plant). The simulations using Solanum paniculatum as a reference plant, as well as using the mean of all references, fell between such extreme values. No reference species is grassy, meaning that they present a very different root system from the fasciculate root system of sugarcane, exploiting differently the soil and being able to present an isotopic signal that does not exactly represent the $\mathrm{N}$ signal of the soil available for sugarcane. In addition, those are species presenting a life cycle shorter than the sugarcane cycle. These facts may show that the \%Ndda estimates presented here underestimate the BNF in sugarcane, since this species must be exploring deeper soil layers 
than the reference species and such layers tend to be isotopically enriched (Bustamante et al. 2004). It is probable that the simulations using sunflowers are closer to the real value of BNF contribution to nitrogen sugarcane nutrition, since this species is the one with the largest size and deepest roots. Similar results were reported by Baptista et al. (2014), in whose study the variations of ${ }^{15} \mathrm{~N}$ in plants used as references presented values similar to those found in this study.

In other countries, such as Australia (Biggs et al. 2002) and South Africa (Hoefsloot et al. 2005), studies have reported that sugarcane is not able to benefit from BNF. However, in Brazil, there is strong evidence that several varieties planted in the country are able to obtain part of the $\mathrm{N}$ accumulated in their biomass from the atmosphere, although at very variable proportions (Baptista et al. 2014), which could explain its production with nitrogen fertilizer quantities much lower than those applied in other countries. Even using the values of $\% \mathrm{Ndda}$ obtained from the average of reference plants, which may be considered conservative, we observed that they are within the range of values commonly reported for sugarcane cultivated in Brazil, which is around $40 \%$. Such responses depend on plant genotype and edaphoclimatic conditions (Reis et al. 2006). However, the information available does not cover much of the diversity of genotypes used and the environmental conditions of the different producing regions. The variety RB92579, one of the most used in the northeast region of Brazil, is still little studied as for its BNF potential. Thus, further studies are important aiming to find and evaluate bacterial strain with high efficiency in the BNF for this variety.

Although it had no effects on productivity or on BNF, the different inoculations had effects on the industrial parameters of sugarcane (Table III). Positive or negative variations were observed for the production of sugars and fibers, suggesting an influence of bacteria on plant physiology (Oliveira et al. 2006), but a response pattern is difficult to be established because such effects varied between cycles. The inoculation with the strain IPACC33 reduced the sugarcane ${ }^{\circ} \mathrm{Brix}$ in relation to the absolute control only during the first cycle, since the mixture IPA-CC9+IPA-CF65 increased the sugarcane Brix over the TN only in the second cycle. Plants inoculated with the mixture IPACC9+IPA-CC33+IPA-CF65 showed higher amounts of fiber than plants inoculated with the EMBRAPA mixed inoculant during the ratoon cane cycle. In the third cycle, there were low fiber contents in plants inoculated with the strain IPACC9. This decrease in fiber content of sugarcane is industrially interesting if the plant is mainly destined to the production of sugar or alcohol, since there is a greater yield in the milling of culms. For industry sectors that use energy biomass for burning, the demand for materials with higher amounts of fiber is more interesting. Prices of sugarcane generally depend on the quality of the raw material (Farias et al. 2009), but, from an agricultural point of view, the high-fiber varieties have a greater resistance to toppling, even when subjected to burning, and are generally more resistant to penetration of culm pests (Lavanholi 2008).

\section{CONCLUSIONS}

For the sugarcane variety RB 92579, the efficiency of inoculation was similar for plant-cane and ratoon cane, with a decrease for second ratoon cane, indicating a non-response of this inoculation to this last cultivation. This study showed that no strain promoted the improvement on yield and biological nitrogen fixation of sugarcane. Industrial characteristics during the three cycles of sugarcane (plant-cane, ratoon cane and second ratoon cane) are affected by inoculation with PGPB. However, further studies should be done with these strains in different sugarcane varieties and also soil conditions in order to select suitable strains for using in commercial inoculants. 


\section{ACKNOWLEDGMENTS}

The authors thank the Coordenação de Aperfeiçoamento de Pessoal de Nível Superior (CAPES), for the Doctoral Sandwich Program Abroad (PDSE) scholarship, Case No. 007284 2014-04, granted to the first author; the Agronomic Institute of Pernambuco (IPA), for the infrastructure and technical support; and the Conselho Nacional de Desenvolvimento Científico e Tecnológico (CNPq, Processes 441305/2017-2 and 426655/2018-4), for the financial support of this study.

\section{AUTHOR CONTRIBUTIONS}

JELA: author of the part of this thesis that generated this paper, developed field experiments and data analysis as well as paper wrote. ADSF: co-advisor of the thesis and collaborated in the field experiments, $\mathrm{N}-15$ analysis and paper writing. LMSO: collaborated in the field experiments. MCCPL: collaborated in the paper writing. MACF: provided planting area, and collaborated in the field experiments. CERSS: collaborated in the field experiments and data analysis. JPO: collaborated in the field experiments. ASFA: co-advisor of the thesis collaborated in the paper writing. MVBF: advisor of the thesis, collaborated in the discussion and data analysis, as well as collaborated in the paper writing and logistic support.

\section{REFERENCES}

ANTUNES JEL, LYRA MCCP, OLLERO FJ, FREITAS ADS, OLIVEIRA LMS, ARAÚJO ASF AND FIGUEIREDO MVB. 2017. Diversity of plant growth-promoting bacteria associated with sugarcane. Genet Mol Res 16: 1-10.

BALDANI JI, REIS VM, VIDEIRA SS, BODDEY LH AND BALDANI VLD. 2014. The art of isolating nitrogenfixing bacteria from non-leguminous plants using $\mathrm{N}$-free semi-solid media: a practical guide for microbiologists. Pant Soil 384: 413-431.

BAPTISTA RB, DE MORAIS RF, LEITE JM, SCHULTZ N, ALVES BJR, BOBBEY RM AND URQUIAGA S. 2014. Variations in the ${ }^{15} \mathrm{~N}$ natural abundance of plantavailable $\mathrm{N}$ with soil depth: Their influence on estimates of contributions of biological $\mathrm{N}_{2}$ fixation to sugar cane. Appl Soil Ecol 73: 124-129.
BENEDUZI A, MOREIRA F, COSTA PB, VARGAS LK, LISBOA BB, FAVRETO R AND PASSAGLIA LMP. 2013. Diversity and plant growth promoting evaluation abilities of bacteria isolated from sugarcane cultivated in the South of Brazil. Appl Soil Ecol 63: 94-104.

BIGGS IM, STEWART GR, WILSON JR AND CRITCHLEY C. $2002 .{ }^{15} \mathrm{~N}$ natural abundance studies $\mathrm{N}$ in Australian commercial sugarcane. Plant Soil 238: 21-30.

BODDEY RM, POLIDORO JC, RESENDE AS, ALVES BJR AND URQUIAGA S. 2001. Use of ${ }^{15} \mathrm{~N}$ natural abundance technique for the quantification of the contribution of $\mathrm{N}_{2}$ fixation to sugar cane and others grasses. Aust J Agric Res 28: 889-895.

BODDEY RM, URQUIAGA S, ALVES BJR AND REIS VM. 2003. Endophytic nitrogen fixation in sugarcane: present knowledge and future applications. Plant Soil 252: 139149.

BUSTAMANTE MMC, MARTINELLI LA, SILVA LA, CAMARGO PB, KLINK CA, DOMINGUES TF AND SANTOS RV. 2004. ${ }^{15} \mathrm{~N}$ natural abundance in woody plants and soils of central Brazilian savannas (Cerrado). Ecol Appl 14: 200-213.

CAVALCANTI FJA, SANTOS JCP, PEREIRA JR, LEITE JP AND SILVA MCL. 2008 Recomendações de adubação para o Estado de Pernambuco: $2^{\mathrm{a}}$ aproximação, $3^{\mathrm{a}}$ ed., Recife-PE: Instituto Agronômico de Pernambuco, 212 p.

CHAVES VA, SANTOS SG, SCHULTZ N, PEREIRA W, SOUSA JS, MONTEIRO RC AND REIS VM. 2015. Desenvolvimento Inicial de Duas Variedades de Cana-deaçúcar Inoculadas com Bactérias Diazotróficas. Rev Bras Ciênc Solo 39: 1595-1602.

CONAB - COMPANHIA NACIONAL DE ABASTECIMENTO. 2018. Acompanhamento de safra brasileira de cana-de-açúcar: Segundo levantamento, agosto 2018 - Safra 2018/19, n.2, Brasília, p.1-86. Available: http://www.conab.gov.br. Accessed October 30, 2018.

DÖBEREINER J AND ALVAHYDO R. 1959. Sobre a influência da cana-de-açúcar na ocorrência de Beijerinckia no solo: Influência das diversas partes do vegetal. Rev Bras Biol 19: 401-412.

DOS SANTOS SG, DA SILVA RF, DA FONSECA CS, PEREIRA W, SANTOS LA AND REIS VM. 2017. Development and nitrate reductase activity of sugarcane inoculated with five diazotrophic strains. Arch Microbiol 199: 863-873.

EMBRAPA - EMPRESA BRASILEIRA DE PESQUISA AGROPECUÁRIA. 2017. Manual de métodos de análise do solo, $3^{\text {a }}$ ed., Brasília, DF, 573 p.

EMBRAPA - EMPRESA BRASILEIRA DE PESQUISA AGROPECUÁRIA. 2013. Sistema brasileiro de classificação de solos, $3^{\mathrm{a}}$ ed., Brasília, DF, 353 p.

FARIAS CHA, FERNANDES PD, GHEYI HR AND NETO JD. 2009. Qualidade industrial de cana-de-açúcar sob irrigação e adubação com zinco, em Tabuleiro Costeiro paraibano Rev Bras Eng Agríc Ambient 13: 419-428. 
FIGUEIREDO MVB, ANTUNES JEL, RODRIGUES AC, GOUVEIA CK, MORAES RLC AND OLIVEIRA JDP. 2013. Fixação biológica de nitrogênio (FBN): bactérias diazotróficas para uma agricultura sustentável. In: Figueiredo MVB et al. (Eds), Manual de práticas laboratoriais: um guia para pesquisa, Recife-PE: CCS Gráfica e Editora, Recife, BRA, p. 33-88.

FREITAS ADS, SAMPAIO EVSB, SANTOS CERS AND FERNANDES AR. 2010. Biological nitrogen fixation in tree legumes of the brazilian semi-arid caatinga. J Arid Environ 74: 344-349.

FREITAS ADS, SAMPAIO EVSB, RAMOS APS, BARBOSA MV, LYRA RP AND ARAÚJO EL. 2015. Nitrogen isotopic patterns in tropical forests along a rainfall gradient in Northeast Brazil. Plant Soil 391: 109-122.

HERRERA JM, RUBIO G, LEVY L, DELGADO LA, LUCHO CCA, ISLAS VS AND VALDEZ SP. 2016. Emerging and established technologies to increase nitrogen use efficiency of cereals. Agronomy 6: 1-19.

HOEFSLOOT G, TERMORSHUIZEN AJ, WATT DA AND CRAMER MD. 2005. Biological nitrogen fixation is not a major contributor to the nitrogen demand of a commercially grown South African sugarcane cultivar. Plant Soil. 277: 85-96.

IBGE - INSTITUO BRASILEIRO DE GEOGRAFIA E ESTATISTICA. 2018. Levantamento sistemático da produção agrícola. Available at: https://sidra.ibge.gov.br/ home/lspa/brasil. Accessed April 20, 2018.

LAVANHOLI MGDP. 2008. Qualidade da cana-de-açúcar como matéria-prima para produção de açúcar e álcool. In: Dinardo-Miranda LLD et al. (Eds), Cana- de-açúcar, Campinas: Instituto Agronômico, Campinas, BRA, p. 697722.

LIMA RC, KOZUSNY-ANDREANI DI, JUNIOR RA AND FONSECA L. 2011. Caracterização fenotípica de bactérias diazotróficas endofíticas isoladas de cana de açúcar. Rev Fac Nac Agron Medellín 64: 5803-5813.

LUGTENBERG B AND KAMILOVA F. 2009. Plant-growthpromoting rhizobacteria. Annu Rev Microbiol 63: 541556.

MARIANO E, OTTO R, MONTEZANO ZF, CANTARELLA H AND TRIVELIN PCO. 2017. Soil nitrogen availability indices as predictors of sugarcane nitrogen requirements. Eur J Agron 89: 25-37.

OLIVEIRA ALM, URQUIAGA S, DÖBEREINER J AND BALDANI JI. 2002. The effect of inoculating endophytic $\mathrm{N}_{2}$-fixing bacteria on micropropagated sugarcane plants. Plant Soil. 242: 205-215.

OLIVEIRA ALM, CANUTO EL, URQUIAGA S, REIS VM AND BALDANI JI. 2006. Yield of micropropagated sugarcane varieties in different soil types following inoculation with diazotrophic bacteria. Plant Soil 284: 2332.

PEDULA RO, SCHUNLTZ N, MONTEIRO R, PEREIRA W, DE ARAÚJO AP, URQUIAGA S AND REIS VM. 2016. Growth analysis of sugarcane inoculated with diazotrophic bacteria and nitrogen fertilization. Afr J Agric Res 11: 2786-2795.

REIS VM, OLIVEIRA ALM, BALDANI VLD, OLIVARES FL AND BALDANI JI. 2006. Fixação biológica de nitrogênio simbiótica e associativa. In: Fernandes MS (Ed), Nutrição Mineral de Plantas, Viçosa-MG: Sociedade Brasileira de Ciência do Solo, Viçosa, BRA, p. 153-174.

ROSSETTO R, CANTARELLA H, DIAS FLF, VITTI AC AND TAVARES S. 2010. CANA- DE-AÇÚCAR. In: Prochnow LI et al. (Eds), Boas práticas para uso eficientes de fertilizantes, Piracicaba-SP: International Plant Nutrition Institute, Piracicaba, BRA, p. 161-230.

SAS INSTITUTE. 2001. SAS/STAT. User's guide, version 8.02, TS level 2MO. SAS Institute Inc., Cary, NC.

SCHULTZ N, PEREIRA W, REIS VM AND URQUIAGA S. 2016. Produtividade e diluição isotópica de $15 \mathrm{~N}$ em cana de açúcar inoculada com bactérias diazotróficas. Pesq Agropec Bras 51: 1594-1601.

SCHULTZ N, SILVA JA, SOUSA JS, MONTEIRO RC, OLIVEIRA RP, CHAVES VA AND URQUIAGA S. 2014. Inoculation of sugarcane with diazotrophic bactéria. Rev Bras Ciênc Solo 38: 407-414.

SHEARER G AND KOHL DH. 1986. $\mathrm{N}_{2}$-Fixation in Field Settings - Estimations Based on Natural N-15 Abundance. Aust J Plant Physiol 13: 699-756.

SHUKLA SK, YADAV RL, SUMAN A AND SINGH PN. 2008. Improving rhizospheric environment and sugarcane ratoon yield through bio-agent amended farm yard manure in Udic Ustochrept soil. Soil Tillage Res 99: 158-168.

SILVA MF, OLIVEIRA PJ, XAVIER GR, RUMJANEK NG AND REIS VM. 2009. Inoculantes formulados com polímeros e bactérias endofíticas para a cultura da canade-açúcar. Pesq Agropec Bras 44: 1437-1443.

URQUIAGA S, XAVIER RP, MORAIS RF, BATISTA RB, SCHULTZ N, LEITE JM AND BODDEY RM. 2012. Evidence from field nitrogen balance and ${ }^{15} \mathrm{~N}$ natural abundance data for the contribution of biological $\mathrm{N}_{2}$ fixation to Brazilian sugarcane varieties. Plant Soil 356: $5-21$.

USDA - UNITED STATES DEPARTAMENT OF AGRICULTURE. 1999. Soil taxonomy: A basic system of soil classification for making and interpreting soil surveys, $2^{\text {nd }}$ ed., Washington, DC, $871 \mathrm{p}$.

USDA - UNITED STATES DEPARTAMENT OF AGRICULTURE. 2018. Reduced Cane Production and Fewer Imports Eclipse the Reduction in Deliveries for 2017/18. Florida, DC, 14 p. (http://usda.mannlib.cornell. edu/usda/ers/SSS//2010s/2018/SSS-06-19-2018.pdf).

VIDEIRA SS, OLIVEIRA DM, MORAIS RF, BORGES WL, BALDANI VLD AND BALDANI JI. 2012. Genetic diversity and plant growth promoting traits of diazotrophic bacteria isolated from two Pennisetum purpureum Schum. genotypes grown in the field. Plant Soil 356: 51-66.

ZHAN J AND SUN Q. 2012. Diversity of free-living nitrogenfixing microorganisms in the rhizosphere and nonrhizosphere of pioneer plants growing on wastelands of copper mine tailings. Microbiol Res 167: 157-165. 